\title{
PHYLOGENY AND MORPHOLOGY OF NEODIDYMELLIOPSIS IRANENSIS SP. NOV., CAUSING DEAD BRANCHES OF CITRUS IN IRAN
}

\author{
Parisa SOLEIMANI, Shahram GOUDARZI \\ Healthy and organic products technology research center, Dezful branch, Islamic Azad University, Dezful, Iran \\ e-mail: soleimani302p@yahoo.com; Goudarzish55@gmail.com
}

\begin{abstract}
Citrus plants, which are mostly cultivated in the southern tropical area of the country, are one of the important economic crops in Iran. Branch canker and dieback of citrus is an ongoing problem for citrus growers located in these areas and has imposed irreparable damage to the citrus production in this region in recent years. Disease symptoms consisted of the blight of vigorously growing shoots and dieback of the branches and rootstock trunks. This study aimed to characterize the citrus dieback pathogen morphologically and phylogenetically, and the species Neodidymelliopsis iranensis Soleimani \& Goudarzi, sp. nov., is described and illustrated here. Isolates were derived from collected citrus samples with dieback symptoms. After preparing pure cultures from single spores on oatmeal agar and malt agar, the morphological features of the species were described and their pathogenicity was confirmed on lime (Citrus aurantifolia). Morphologically $N$. iranensis is easily separated from the other species of Neodidymelliopsis by the size of pycnidia, conidia septation, and $\mathrm{NaOH}$ test results. The morphological differences between our isolates and the other known species of Neodidymelliopsis were strongly supported by a multi-locus phylogenetic analysis based on the ITS region, and $L S U, R P B 2$, and TUB2 genes. In the reconstructed phylogenetic tree, $N$. iranensis formed a well-supported clade with other Neodiddymelliopsis species in the Didymellaceae family, but was separated from all other Neodiddymelliopsis species. The distinct phylogenetic position is supported by differences in morphological features. Consequently, the specificity of the morphological and phylogenetical features of the collected isolates has convinced us to describe Neodidymelliopsis iranensis as a new species.
\end{abstract}

Keywords: Citrus, Didymellaceae, Morphology, Pathogenicity, Phylogeny.

\section{Introduction}

Citrus are among the ten most important crops in terms of total fruit yield worldwide [10]. More than nine million hectares are planted with citrus throughout the world, a total production of c.146 million tonnes (FAO, 2016). Iran, with over 214,000 ha of citrus plantations and about $3,700,000$ tonnes of citrus fruit production, has been ranked 10th in the world for this crop.

Citrus are affected by several diseases and pests. Dieback disease of citrus has caused increasing alarm to citrus growers located in the south of Iran, in that in many plantations the yield has been halved or reduced to nil. Canker and dieback diseases are common, destructive, and continue to be extensively studied in a wide range of woody plants [21]. Branch canker and dieback diseases of citrus have been reported since the early 1900s. Symptoms of these diseases generally include the presence of the dead, sunken bark around dark-colored cankers, twig and branch dieback, and gummosis. Many factors contribute to the occurrence of such symptoms. Fungi and fungi-like microorganisms have the greatest role in the occurrence of these symptoms [21]. Citrus have been threatened by parasitic pycnidial fungi for several decades. Several fungal taxa 
belonging to the different families of Botryosphaeriaceae and Didymellaceae [12, 24] have been reported from the dead citrus branches: Barriopsis fusca [24], Didymella microchlamydospora [5], Diplodia striataI [24], Lasiodiplodia citricola, L. iraniensis [2], L. mediterranea [19], L. pseudotheobromae [2], Neofusicoccum ribis [13], Phaeobotryosphaeria citrigena [24], Spencermartinsia citricola, S. plurivora [1] and Phaeobotryosphaeria citrigena [24].

The new genus Neodidymelliopsis Q. Chen \& L. Cai was recently proposed by Chen et al. (2015) with five species, including Neodidymelliopsis longoicolla L.W. Hou, Crous \& L. Cai, $N$. achlydis L.W. Hou, Crous \& L.Cai, N. cannabis (G. Winter) Q. Chen \& L. Cai, N. polemonii Q. Chen \& L. Cai, and N. xanthina (Sacc.) Q. Chen \& L. Cai. These have been already isolated from soil in the desert and living or dead aerial parts of different plants such as Achlys triphylla, Cannabis sativa, Urtica dioica, Polemonium acutiflorum and Delphinium spp. [10, 12, 31] Recently, N. farrokhinejadii was added to this genus [4] within the recently established family Didymellaceae [15]. The family embraces the species traditionally classified in the genera Ascochyta, Didymella, and Phoma [31]. Members of this family are pathogenic on a wide range of host plants, which mainly cause leaf and stem lesions and dieback disease $[6,11]$. Molecular phylogenetic studies have shown that the family Didymellaceae includes most members of Phoma and related asexual genera, including Didymella, Epicoccum, Allophoma, Heterophoma, Stagonosporopsis, Phoma, Boeremia, Paraboeremia, Ectophoma, Remotididymella, Similiphoma, Cumuliphoma, Juxtiphoma, Vacuiphoma, Briansuttonomyces, Pseudoascochyta, Neomicrosphaeropsis, Macroventuria, Nothophoma, Ascochyta, Calophoma, Leptosphaerulina, Phomatodes, Neoascochyta, Xenodidymella, and Neodidymelliopsis [11, 12, 31].

In the present study, we collected Phoma-like fungi that caused dieback of citrus in the south of Iran. Citrus plants are one of the important economic crops in Iran, and thus taking appropriate and efficient strategies to manage their pathogens depends on a good knowledge of their taxonomy, pathogenicity, diversity, and ecology. Consequently, the objectives of this study were to (1) determine the taxonomy of collected isolates based on their morphological features and phylogenetic relationship with the other known taxa within the Didymellaceae (2) assess the pathogenicity and aggressiveness of these fungi on lime (Citrus aurantifolia).

\section{Materials and Methods}

\section{Sample collection and pathogen isolation}

Sample collection was performed as described by Adesemoye et al. (2014) from five citrusgrowing provinces located in the south of Iran - Khuzestan, Kerman, Hormozgan, Fars and Kohkiluiae - from 2014 to 2016. Citrus branch samples with dieback, yellowing, defoliation and the symptoms of blight on vigorously growing shoots were collected from 10 randomly selected trees in each of 5 to 10 orchards per province, depending on orchard density. The samples were packed in paper bags and transferred to the laboratory. Pathogen isolation and propagation were performed according to the methods described by Taylor and Hyde [30]. The small pieces (0.5-1 $\mathrm{cm}$ ) of infected tissue, taken from the junction of the diseased and healthy areas of the samples, were excised and surface-sterilized by dipping them in $0.5-1 \% \mathrm{NaOCl}(2-4$ minutes), followed by washing three times with sterile distilled water $(2 \mathrm{~min})$ and plated on potato dextrose agar medium (PDA, Difco, USA) amended with $0.01 \%$ tetracycline. The plates were incubated in the dark up to $5-15$ days at $25 \pm 2{ }^{\circ} \mathrm{C}$. The isolates were purified by the single spore method and individual small colonies sub-cultured on PDA. Then, three isolates were selected as representatives, and their 
morphological and molecular characteristics were evaluated carefully. The host and geographical location of these collected isolates were displayed in Table 1.

\section{Mycological examination}

The morphological properties of colonies were determined using the manual of Boerema et al. (2004). Isolates were cultivated on oatmeal agar (OA), potato dextrose agar (PDA) and malt extract agar (MEA). Plates were incubated in complete darkness at $20-22^{\circ} \mathrm{C}$ for 7 days. During a second week, the Petri dishes were placed at 13/11 h alternating NUV light and dark period to stimulate the pigmentation of the colonies and the formation of pycnidia. Colony diameters and morphologies were recorded 8 and 15 days after culture incubation. Rayners' colour chart [25] was used to rate the colours of each colony and detected the production of metabolite $\mathrm{E}+\mathrm{using}$ a droplet of $1 \mathrm{~N} \mathrm{NaOH}$ [8]. Finally, the cultured fungal colony preparations were mounted on glass slides with clear lactic acid for microscopic examination. The structure of the pycnidial wall and the shape of conidiogenous cells were analyzed in hand-cut sections of pycnidium. Conidia and pycnidia were measured in 30 rounds. An Olympus (DP25) digital camera installed on a BX50 Olympus light microscope was used for the illustration. The identification of fungi was based on morphological characteristics as described by Boerema et al. $(2004)$, Chen et al. $(2015,2017)$ and Valenzuela-Lopez et al. (2018). Fungi isolates of this study were deposited at Centraalbureau voor Schimmelcultures (CBS) Fungal Biodiversity Center in the Netherlands and Iranian Fungal Culture Collection (IRAN.C) at the Iranian Research Institute of Plant Protection (Table 2).

Table 1: The host and geographical location of collected isolates

\begin{tabular}{c|c|c|c|c|l|l}
\hline Isolate number & Province & Region & Host & Height & Longitude & latitude \\
\hline CBS 142208 & Kerman & Anbar abad & Citrus sinensis & 607 & 28.4683630 & 57.8514833 \\
CBS 142211 & Khuzestan & Dezful & Citrus paradisi & 110 & 32.3268267 & 48.4169164 \\
CBS 142210 & Fars & Jahrom & Citrus aurantium & 1098 & 28.5284902 & 53.5066273 \\
\hline
\end{tabular}

Table 2: Isolates considered in this study. Newly generated sequences are indicated in bold

\begin{tabular}{|c|c|c|c|c|c|c|c|}
\hline \multirow[t]{2}{*}{ Species name } & \multirow{2}{*}{$\begin{array}{c}\text { Strain } \\
\text { number }\end{array}$} & \multirow{2}{*}{$\begin{array}{c}\text { Host, } \\
\text { substra } \\
\text { te } \\
\end{array}$} & \multirow[t]{2}{*}{ Country } & \multicolumn{4}{|c|}{ GenBank accession numbers } \\
\hline & & & & $\boldsymbol{L S U}$ & $I T S$ & RPB2 & $T U B$ \\
\hline $\begin{array}{l}\text { Neoascochyta } \\
\text { desmazieri }\end{array}$ & CBS 247.79 & $\begin{array}{l}\text { Graminea } \\
e\end{array}$ & Austria & KT389725 & KT389507 & - & KT389805 \\
\hline $\begin{array}{l}\text { Neoascochyta } \\
\text { desmazieri }\end{array}$ & CBS 297.69 & $\begin{array}{l}\text { Lolium } \\
\text { perenne }\end{array}$ & Germany & KT389726 & KT389508 & KT389644 & KT389806 \\
\hline $\begin{array}{l}\text { Neoascochyta } \\
\text { desmazieri }\end{array}$ & CBS 758.97 & Hay & Norway & KT389727 & KT389509 & - & KT389807 \\
\hline $\begin{array}{l}\text { Neoa. } \\
\text { europaea }\end{array}$ & CBS 819.84 & $\begin{array}{l}\text { Hordeum } \\
\text { vulgare }\end{array}$ & Germany & KT389808 & KT389728 & KT389510 & KT389645 \\
\hline $\begin{array}{l}\text { Neoa. } \\
\text { europaea }\end{array}$ & CBS 820.84 & $\begin{array}{l}\text { Hordeum } \\
\text { vulgare }\end{array}$ & Germany & KT389729 & KT389511 & KT389646 & KT389809 \\
\hline \multirow[t]{5}{*}{$\begin{array}{l}\text { Neoa. } \\
\text { graminicola }\end{array}$} & CBS 301.69 & $\begin{array}{l}\text { Lolium } \\
\text { multifloru } \\
m\end{array}$ & Germany & KT389737 & KT389519 & KT389650 & KT389817 \\
\hline & CBS 447.82 & $\begin{array}{l}\text { Triticum } \\
\text { aestivum }\end{array}$ & Germany & KT389738 & KT389520 & - & KT389818 \\
\hline & CBS 586.79 & $\begin{array}{l}\text { Hordeum } \\
\text { vulgare }\end{array}$ & Belgium & KT389739 & KT389521 & - & KT389819 \\
\hline & CBS 816.84 & $\begin{array}{l}\text { Hordeum } \\
\text { vulgare }\end{array}$ & Germany & KT389741 & KT389523 & KT389651 & KT389821 \\
\hline & CBS 102789 & $\begin{array}{l}\text { Lolium } \\
\text { perenne }\end{array}$ & $\begin{array}{l}\text { New } \\
\text { Zealand }\end{array}$ & KT389736 & KT389518 & KT389649 & KT389816 \\
\hline Neoa. exitialis & CBS 118.40 & - & - & KT389732 & KT389514 & KT389647 & KT389812 \\
\hline
\end{tabular}




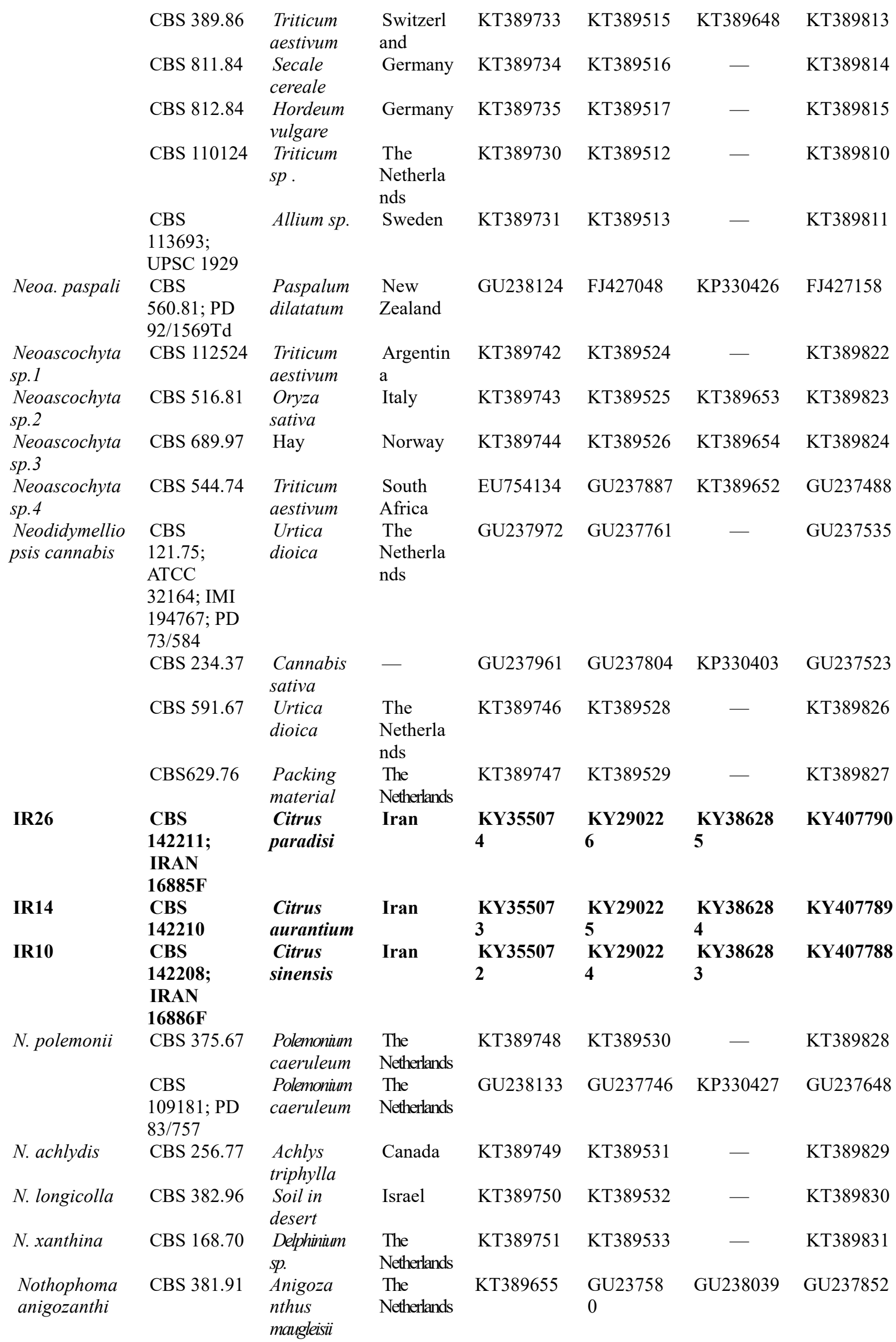




\begin{tabular}{|c|c|c|c|c|c|c|c|}
\hline \multirow[t]{4}{*}{$\begin{array}{l}\text { Xenodidymell } \\
\text { a applanata }\end{array}$} & CBS 195.36 & $\begin{array}{l}\text { Rubus } \\
\text { idaeus }\end{array}$ & $\begin{array}{l}\text { The } \\
\text { Netherlands }\end{array}$ & KT389764 & KT389548 & - & KT389852 \\
\hline & CBS 205.63 & $\begin{array}{l}\text { Rubus } \\
\text { idaeus }\end{array}$ & $\begin{array}{l}\text { The } \\
\text { Netherlands }\end{array}$ & GU237998 & GU237798 & KP330402 & GU237556 \\
\hline & CBS 115577 & $\begin{array}{l}\text { Rubus } \\
\text { idaeus }\end{array}$ & Sweden & KT389762 & KT389546 & KT389688 & KT389850 \\
\hline & CBS 115578 & $\begin{array}{l}\text { Rubus } \\
\text { arcticus } \\
\text { nothossp. } \\
\text { stellarcticus }\end{array}$ & Sweden & KT389763 & КT389547 & - & КТ389851 \\
\hline \multirow[t]{2}{*}{$X$. asphodeli } & CBS 375.62 & $\begin{array}{l}\text { Asphodelus } \\
\text { albus }\end{array}$ & France & KT389765 & KT389549 & KT389689 & - \\
\hline & CBS 499.72 & $\begin{array}{l}\text { Asphodelus } \\
\text { ramosus }\end{array}$ & Italy & KT389766 & КТ389550 & - & KT389853 \\
\hline$X$. catariae & $\begin{array}{l}\text { CBS } \\
102635 ; \mathrm{PD} \\
77 / 1131\end{array}$ & $\begin{array}{l}\text { Nepeta } \\
\text { catenaria }\end{array}$ & $\begin{array}{l}\text { The } \\
\text { Netherlands }\end{array}$ & GU237962 & GU237727 & KP330404 & GU237524 \\
\hline X. humicola & $\begin{array}{l}\text { CBS } \\
220.85 ; \text { PD } \\
71 / 1030\end{array}$ & $\begin{array}{l}\text { Franseria } \\
s p\end{array}$ & USA & GU238086 & GU237800 & KP330422 & GU237617 \\
\hline
\end{tabular}

\section{Pathogenicity test}

Pathogenicity of isolates to lime (Citrus aurantifolia) was confirmed by inoculation of rootstocks with isolate mycelial plugs, in the middle of spring as described by Damm et al. (2007). The branches were wounded with a cork borer to remove the bark and mycelial plugs of a singleconidial isolate $\left(5 \mathrm{~mm}\right.$ diam) grown on PDA at $25^{\circ} \mathrm{C}$ were placed into the wound and the plants maintained in an open area. After inoculation, the branches were wrapped with parafilm. Three seedlings were maintained as a control treatment and were inoculated with sterile PDA, and the plants were assessed 2 months after inoculation. The pathogen was re-isolated from the infected plants and the morphological features of the resultant cultures were checked to confirm Koch's postulates.

\section{DNA extraction, amplification, and sequencing}

For molecular identifications, the procedure described by Doyle and Doyle (1987), was used to extract genomic DNA from fresh fungal mycelium cultivated on PDA media at $25-27^{\circ} \mathrm{C}$ for 4 weeks. The extracted DNA samples were diluted $10 \times$ in distilled water and stored at $4{ }^{\circ} \mathrm{C}$ for further steps. The $L S U, I T S, R P B 2$ and $T U B$ regions were amplified by polymerase chain reaction (PCR), respectively using LR0R/LR7 [26, 32], V9G/ ITS4 [16,33], RPB2-5F2/ fRPB2-7cR [28, 20], and Btub2Fd/Btub4Rd [34], primer pairs, as described by Chen et al. (2015). The conditions of PCR amplifications were as described by Chen et al. (2015). A total volume of $12.5 \mu$ l solution containing $0.5 \mu \mathrm{L} 10 \times$ diluted template DNA, $1 \times$ PCR buffer, $0.4 \mu \mathrm{M}$ of each primer, 1 Unit Taq polymerase, $25 \mu \mathrm{M}$ of each of the $\mathrm{dNTP}, 2 \mathrm{mM} \mathrm{MgCl} 2$. After analyzing the PCR products by electrophoresis in a $1.0 \%(\mathrm{w} / \mathrm{v})$ agarose gel containing $0.1 \mathrm{ug} / \mathrm{mL}$ ethidium bromide in $1 \times \mathrm{TAE}$ buffer (0.4 M Tris, 0.05 M glacial acetic acid 0.01 M ethylenediaminetetraacetic acid [EDTA], pH 7.85), the amplicons were visualized under UV light and were sequenced by the Macrogen company in South Korea.

\section{Phylogenetic analyses}

Single gene and concatenated multi-locus dataset sequences of the 3 isolates recovered in 
this study as well as related sequences, which were mostly published by Aveskamp et al. (2010), Chen et al. $(2015,2017)$ and Valenzuela-Lopez et al. (2018), retrieved from geneBank were aligned, using Clustal X2. The regions which were absent in more than $90 \%$ of the sequences were removed and gaps were treated as missing data. Nothophoma anigozanthi CBS 381.91 was used as the outgroup taxon in the analysis. We inferred the substitution model that best fits the model of DNA evolution using MrModeltest2 v. 2.3. [22]. Finally, the phylogenetic analysis was done by PAUP* v.4.0b10 [29], MrBayes v3.1.2 [18], and RAxML [27], which are based on maximum parsimony (MP), Bayesian inference (BI) and maximum likelihood (ML), respectively.

For maximum-parsimony (MP) analysis with PAUP*, we used the heuristic search option with 1,000 random sequences addition. Maxtrees were set up to 5000 with tree-bisection reconnection (TBR) as the branch-swapping algorithm. The robustness of the trees was evaluated by 1000 bootstrap replications. Moreover, tree length (TL), consistency index (CI), retention index (RI) and rescaled consistency index (RC), were calculated.

Suitable models for the Bayesian analysis were first selected, using models of nucleotide substitution for each gene, as determined using MrModeltest2 v. 2.3. [22]. The Bayesian tree inference (BI) with a Markov Chain Monte Carlo (MCMC) in MrBayes was based on $5 \mathrm{M}$ generations saving one tree per 1000 generations. Four MCMC chains were running simultaneously and automatically ended when the standard deviation of split frequencies was below 0.01 . The first $25 \%$ of the saved trees, which represent the 'burn-in' phase, were discarded. RAxML analysis was performed on the XSEDE supercomputer at the CIPRES Gateway platform. Finally, the reconstructed trees were visualized in TreeView v. 1.6.6. [23]. New sequences were deposited in GenBank (Table 2).

\section{Results}

\section{Pathogenicity test}

Disease symptoms were assessed 2 months after inoculation. Symptoms were the typical pink to brown wood and vessel discoloration expanded rapidly in a longitudinal direction, leaf drop, and the twigs and branches dieback. The cultivation of the fungi derived from symptomatic rootstocks on PDA confirmed the pathogenicity of these isolates. These isolates were identified again as previously described. No symptoms were observed in the control plants (Fig. 1). The experiment was carried out using three replicates and was repeated three times with the same results.

\section{Mycological examination}

The colony characteristics of these three collected isolates (CBS 142208, CBS 142210, CBS 142211) differed from each other, so macroscopic characteristics of each separately mentioned as below. The microscopic characteristics of all three isolates are the same.

Neodidymelliopsis sp. CBS 142210 (MycoBank no.: MB 820336).

IRAN, Fars province, Citrus aurantium, 25 Jun 2013, Soleimani P. (TUB)

Gene sequences: KY355073 (LSU), KY290225 (ITS), KY386284 (PRB2), KY407789

Culture characteristics

Colonies on MA, 5- $5.5 \mathrm{~cm}$ diam, pinkish-white, regular after 7 days, change to pale brown and completely filling the plate after 14 days (Fig 2. A,B). 


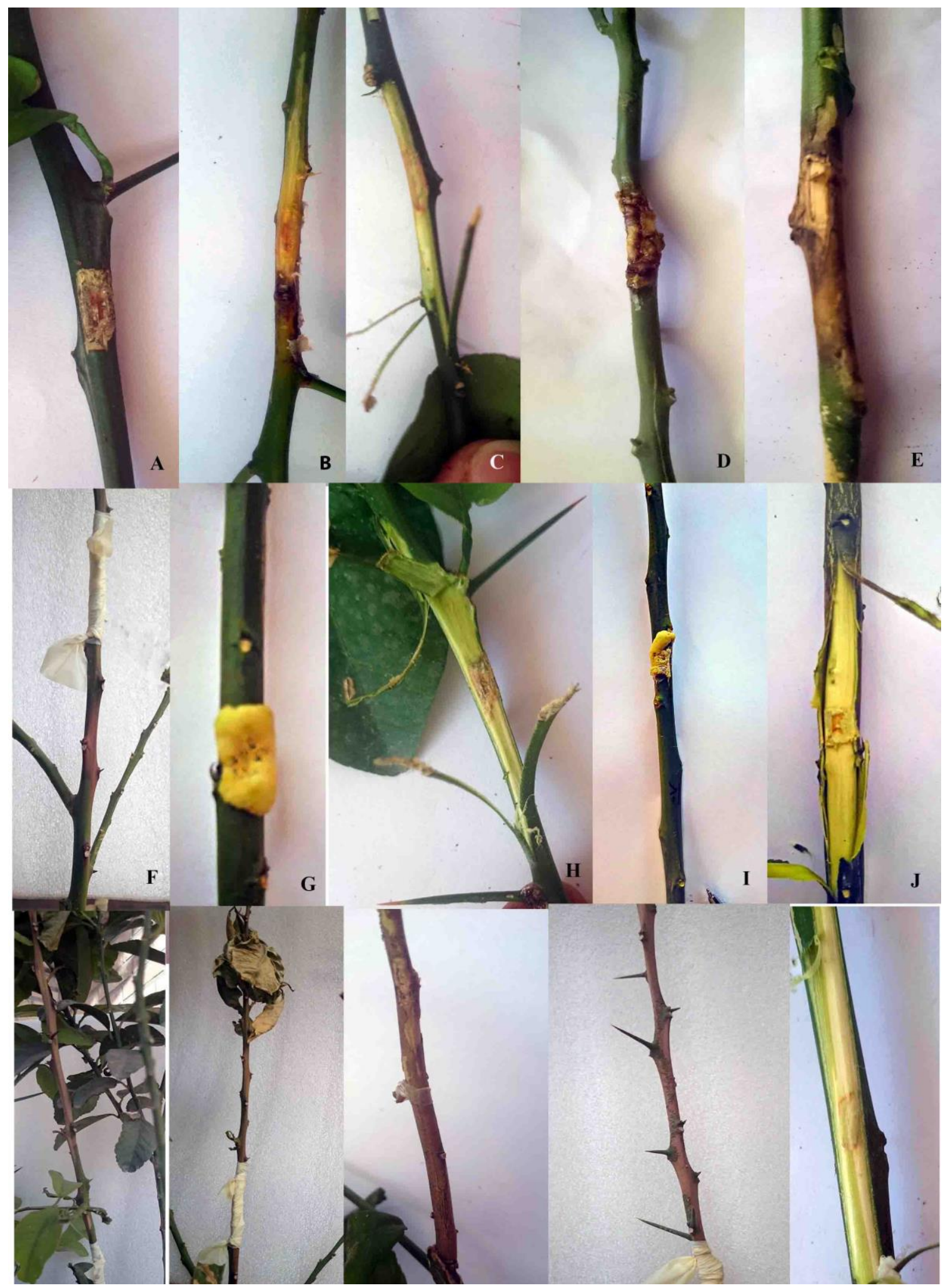

Fig. 1: Symptoms of Neodidymelliopsis sp. on Citrus aurantifolia 2 months after inoculation A, B, C, D, E, F, G, H, I, J, K, L, M \&N inoculated rootstocks with Neodidymelliopsis sp. O control rootstock, inoculated with sterile PDA. Typical pink to brown wood and vessel discoloration A-E , H-J. The twigs dieback F, K-N. Control rootstock O.

Colonies on $O A, 4.5-5.5 \mathrm{~cm}$ diam, colorless, regular after 7 days, black pycnidia are visible 
near the centre, changing to black with concentric pycnidial rings, and completely filling the plate after 14 days (Fig2. C,D).

Colonies on PDA, 4.5- $5 \mathrm{~cm}$ diam, pinkish-brown near the centre and pale greyish-pink near the margin, with olivaceous grey aerial mycelia near the centre, regular after 7 days, changing to pale brown and completely filling the plate after 14 days (Fig2. E,F).

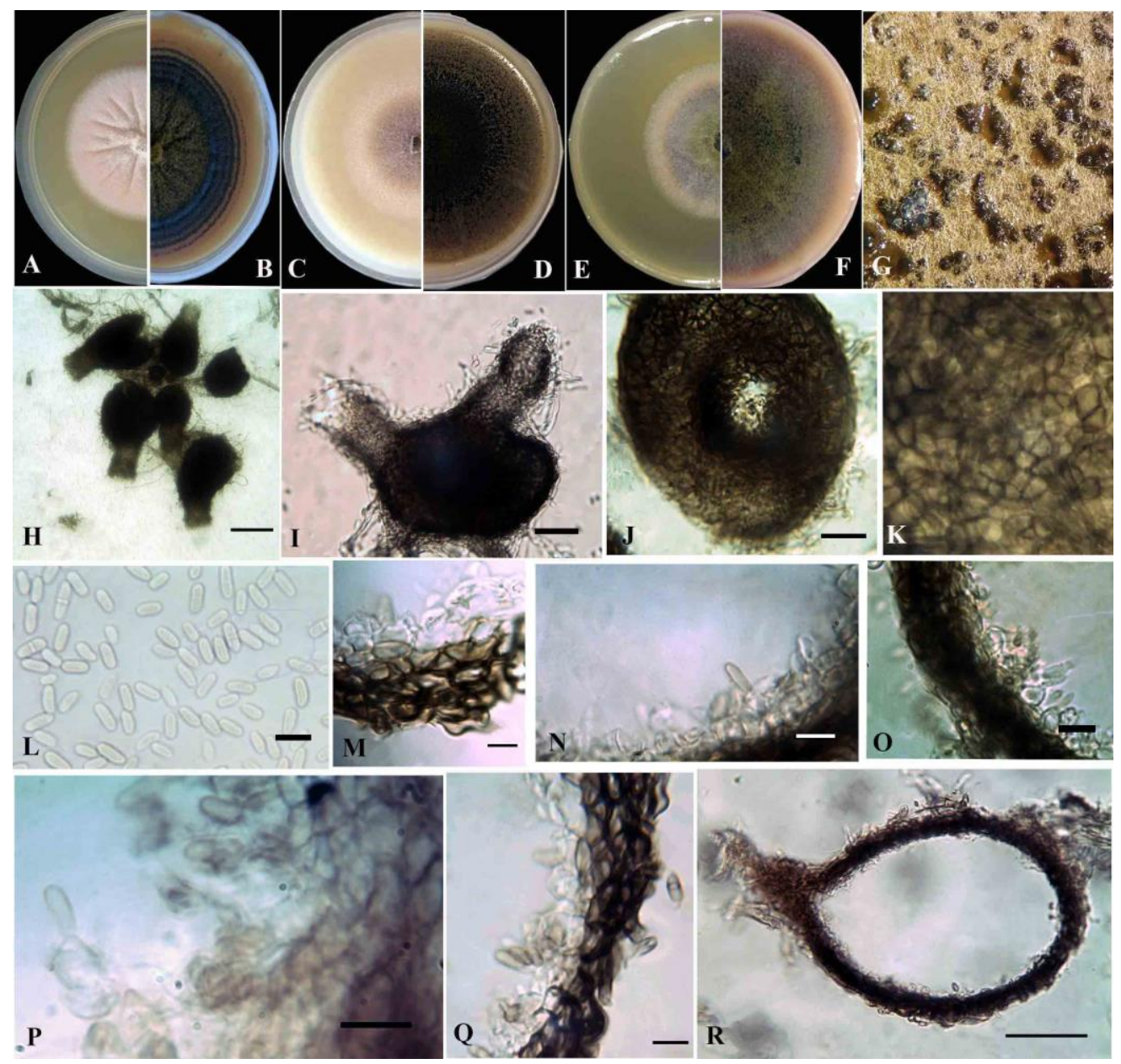

Fig. 2: Neodidymelliopsis sp. (CBS 142210)

A-B. Colony on MA (after one and two weeks). C-D, Colony on OA (after one and two weeks). E-F. Colony on PDA (after one and two weeks). G. Pycnidia forming on OA. H. I, Pycnidium. J, Ostiole. K, pycnidial wall. L, Conidia. M. Q. R, Section of pycnidial wall. N. O. P, Conidiogenous cell. Scale bars: $\mathrm{H}=60 \mu \mathrm{m} ; \mathrm{I}=15 \mu \mathrm{m} ; \mathrm{J}=20 \mu \mathrm{m} ; \mathrm{L}=7$ $\mu \mathrm{m} ; \mathrm{M}, \mathrm{O}, \mathrm{Q}=7 ; \mathrm{N}=10 \mu \mathrm{m} ; \mathrm{P}=15 \mu \mathrm{m}, \mathrm{R}=70 \mu \mathrm{m}$.

Neodidymelliopsis sp. CBS 142208 (MycoBank no.: MB 820339).

IRAN, Kerman province, Citrus sinensis, 24 Aug 2013, Soleimani P.

Gene sequences: KY355072 (LSU), KY290224 (ITS), KY386283 (PRB2), KY407788 (TUB)

\section{Culture characteristics}

Colonies on MA, 5-5.5 cm diam, pale pink, compact, covered by densely white-felty aerial mycelium, regular after 7 days, changing to pale brown and completely filling the plate after 14 days (Fig.3 A,B).

Colonies on $O A, 5-5.5 \mathrm{~cm}$ diam, white near the margins; olivaceous grey near the centre, 
aerial mycelium, white, change to olivaceous grey (Fig.3 C,D).

Colonies on PDA, 4.5-5 cm diam. After 7 days, margin regular, pale brown in the centre, pink near the colony margin, covered by white floccose aerial mycelia, changing to olivaceous grey after 14 days (Fig. 3 E,F).

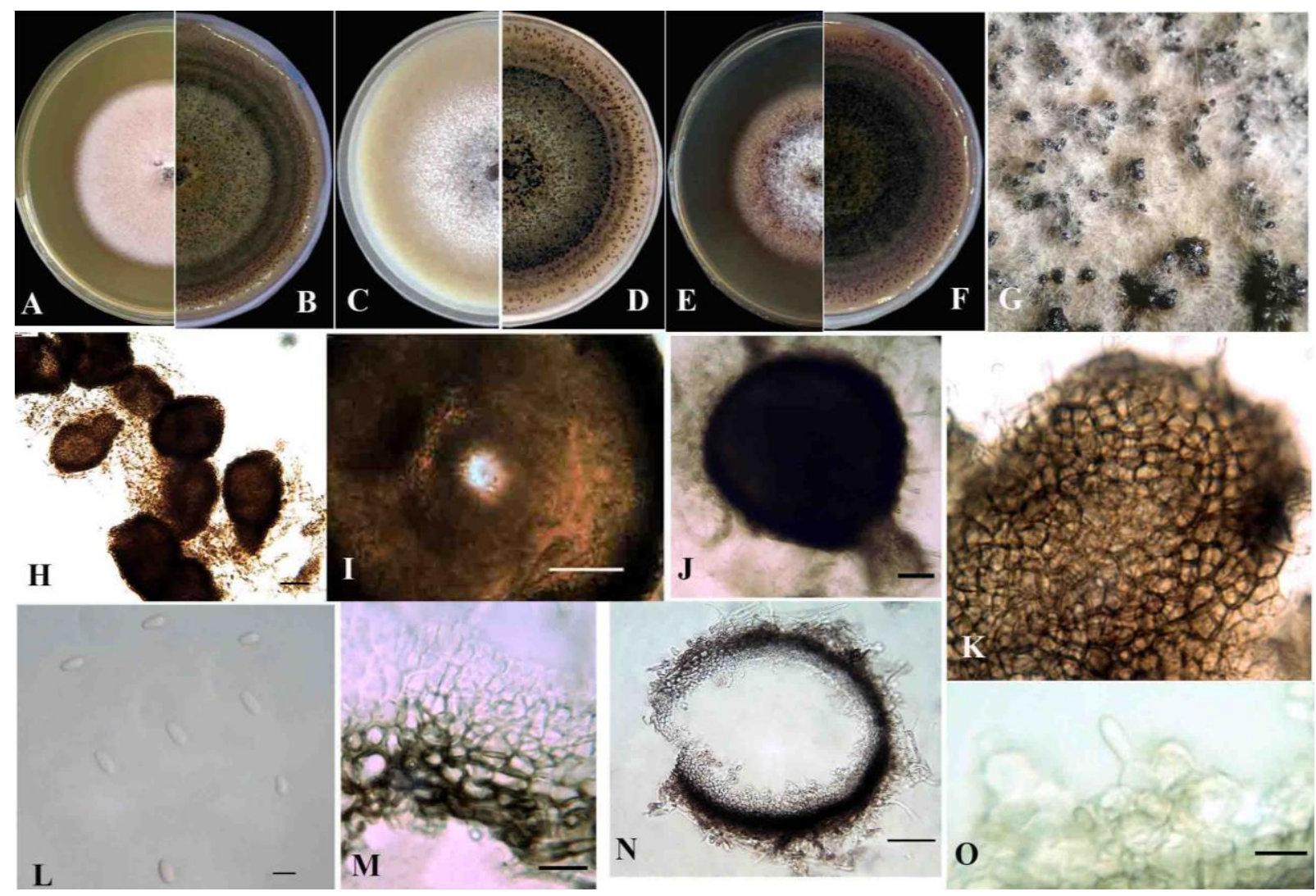

Fig. 3: Neodidymelliopsis sp. (CBS 142208)

A-B, Colony on MA (after one and two weeks). C-D, Colony on OA (after one and two weeks). E-F, Colony on PDA (after one and two weeks). G. Pycnidia forming on OA. H. J, Pycnidium. I, Ostiole. K, pycnidial wall. L, Conidia. M. $\mathrm{N}$, Section of pycnidial wall. $\mathrm{O}$, Conidiogenous cell. Scale bars: $\mathrm{H}=70 \mu \mathrm{m} ; \mathrm{I}=30 \mu \mathrm{m} ; \mathrm{J}=20 \mu \mathrm{m} ; \mathrm{L}=3 ; \mathrm{M}, \mathrm{O}=10$ $\mu \mathrm{m}, \mathrm{N}=25 \mu \mathrm{m}$.

Neodidymelliopsis sp. CBS 142211 (MycoBank no.: MB 820338)

IRAN, Khuzestan province, Citrus paradisi, 4 Sep 2014, Soleimani P.

Gene sequences: KY355074 (LSU), KY290226 (ITS), KY386285 (PRB2), KY407790 (TUB)

Culture characteristics Colonies on MA, 4.5-5 cm diam, after 7 days, margin crenate, pink with honey and light brown zone, with pinkish aerial mycelium, changing to pale brown and completely filling the plate after 14 days (Fig.4 A,B).

Colonies on $O A, 3.5-4 \mathrm{~cm}$ diam, after 7 days, without aerial mycelium, with abundant scattered dark brown pycnidia, margin regular, changing to black with concentric pycnidial rings, and completely filling the plate after 14 days (Fig.4 C,D). 


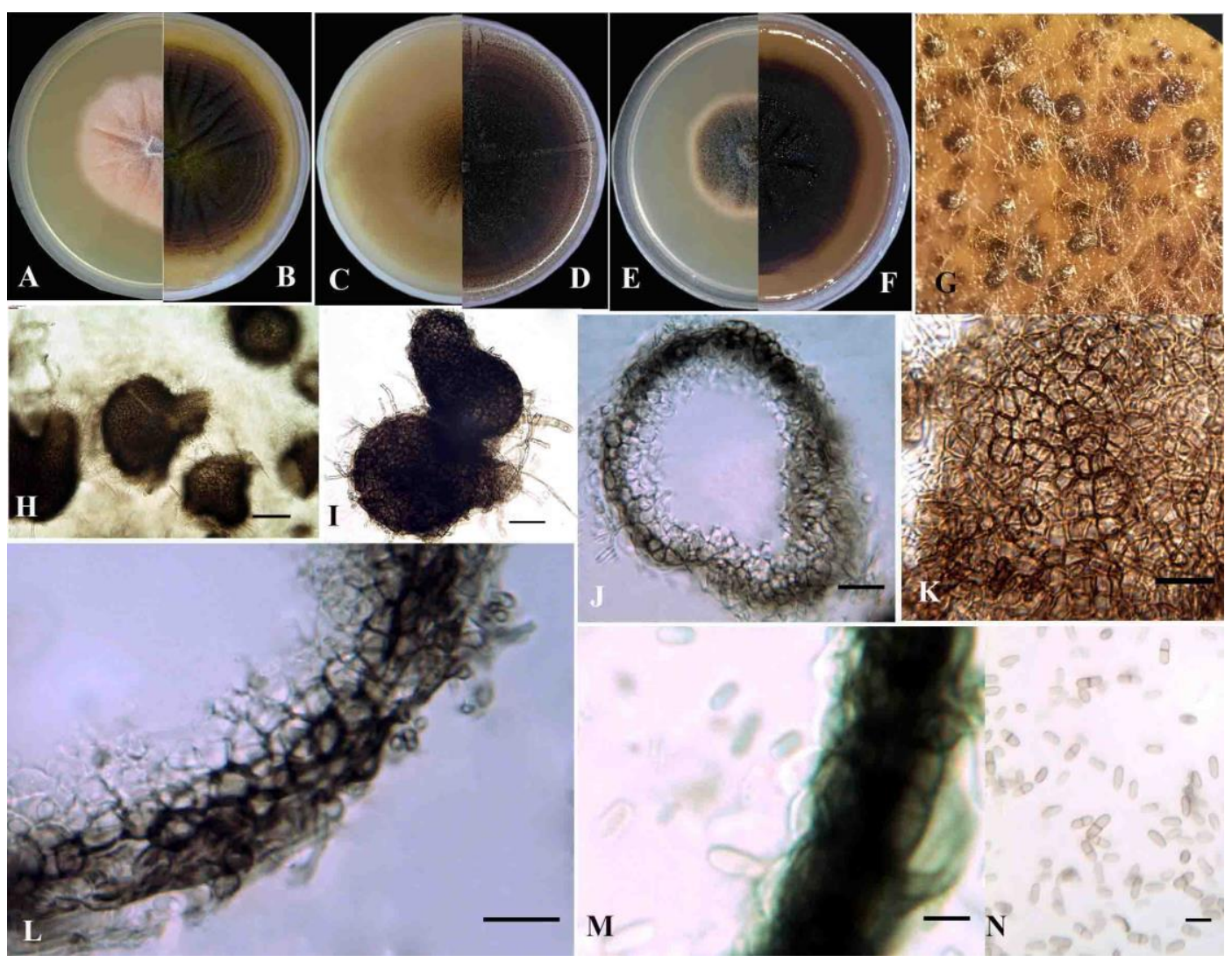

Fig. 4: Neodidymelliopsis sp. (CBS 142211)

A-B, Colony on MA (after one and two weeks). C-D, Colony on OA (after one and two weeks). E-F, Colony on PDA (after one and two weeks). G, Pycnidia forming on OA. H-I, Pycnidium. J. L, Section of pycnidial wall. K, pycnidial wall. $\mathrm{M}$, Conidiogenous cell. $\mathrm{N}$, Conidia. Scale bars: $\mathrm{H}=100 \mu \mathrm{m} ; \mathrm{I}=50 \mu \mathrm{m} ; \mathrm{J}=20 \mu \mathrm{m} ; \mathrm{K}=7 \mu \mathrm{m} ; \mathrm{L}=10 \mu \mathrm{m} ; \mathrm{M}-$ $\mathrm{N}=6 \mu \mathrm{m}$.

Colonies on PDA, 4-4.5 cm diam, after 7 days, dark brown with pinkish margin, covered by densely olivaceous brown aerial mycelia, margin regular, black pycnidia are visible near the centre after 7 days, changing to black with concentric pycnidial rings, and completely filling the plate after 14 days (Fig. 4 E,F).

Conidiomata pycnidial, variable in shape and size, scattered or in concentric rings, solitary or confluent, superficial on or immersed into the agar, globose or sub-globose or flaskshaped, often elongated or irregular, with some hyphal outgrows, variable in dimensions, mostly 55.082-283.98 × 28.046-221.53 diam (Fig. 2 G-J) (Fig. 3 H-J) (Fig.4 H,I).

Ostioles, 1-4, on elongated neck sometimes on a short neck. Pycnidial wall, pseudoparenchymatous, 4-6 layered, 3.8-13.19 $\mu \mathrm{m}$ thick., outer wall pigmented (Fig. $2 \mathrm{~K}, \mathrm{M}, \mathrm{Q}$ ) (Fig. 3 K,M,N) (Fig. 4 J-L).

Conidiogenous cells, phialidic, hyaline, smooth, ampulliform to doliiform, 3.5-7.8 $\times 4.8$ $8.7 \mu \mathrm{m}$ (Fig. 2 O,P) (Fig. 3 O) (Fig. 4 M). Conidia, ovoid, ellipsoid to cylindrical, 0-1 septate, 4.9$9.29 \times 2.3-3.48 \mu \mathrm{m}$, smooth- and thin-walled, hyaline to pale brown (Fig. 2 L) (Fig. 3 L) (Fig. 4 $\mathrm{N})$. Application of $\mathrm{NaOH}$ resulted in a reddish discoloration. 


\section{Phylogenetic analyses}

Three different MP, Bayesian inference and ML methods were provided with the concatenation of the alignments of the $L S U, I T S, R P B_{2}$ and $T U B$ genetic regions in 46 selected taxa (Table 2). The combined $L S U, I T S, R P B_{2}$ and $T U B$ alignments had 2,384 characters including the alignment gaps. The reconstructed trees drawn in TreeView were highly similar in topology, and the selected outgroup taxon, Nothophoma anigozanthi CBS 381.91 was basal to the major clade in all the reconstructed trees.

From the 961 characters of the $L S U$ alignment, 911 were constant, 19 were informative non-parsimony, and 31 were informative parsimony. These numbers for ITS alignment with 490 characters were, respectively, 385, 14 and 91; for the RPB2 alignment with 596 characters were, 389, 25 and 182; and finally for the $T U B$ alignment with 337 characters were, 209, 20 and 108 characters. The concatenated alignment of the four genes with 2,384 total characters consisted of 1,894 constant, 78 informative non-parsimony and 412 informative parsimony characters. A MP heuristic search produced a single most parsimonious tree with a length of 1187 steps $(\mathrm{CI}=0.561$, $\mathrm{RI}=0.867, \mathrm{RC}=0.486, \mathrm{HI}=0.439)$. Dirichlet base frequencies and the $\mathrm{GTR}+\mathrm{I}+\mathrm{G}$ model with inverse gamma rates were determined as the best for the combined and individual gene alignments to be set in MrBayes. The topology and support values of the MP trees were in congruence with $\mathrm{BI}$ and ML trees (Fig. 5). Analysis of the combined dataset from the ITS region and LSU, PRB2 and $T U B$ genes successfully resolved the phylogeny of the three isolates of Neodidymelliopsis-like fungus of this study (CBS 142208, CBS 142210, CBS 142211) with high bootstrap support. These isolates formed a clade with the species of Neodidymelliopsis with strong support (1.00 PP / 100\% ML / 100\% MP) and separated from Neodidymelliopsis longicolla CBS 382.96 and $N$. farrokhinejadii CBS 142850 with a high support (1.00 PP / 100\% ML / 99\% MP) and were not conspecific with any other species in the NCBI.

\section{Discussion}

The dieback and decline of citrus trees have recently been recorded in the orchards at the centre of citrus cultivation in the south of Iran. Thus far, several pathogenic genera like Didymella, Dothiorella, and Neoscytalidium fungi have been isolated from symptomatic plants. This study reports the Neodidymelliopsis as responsible for dieback symptoms in citrus orchards of Iran and describes the taxonomic features of the fungus.

Comparing the morphological features of the present study isolates showed that they share Didymellaceae properties. These isolates, like other species in the Didymellaceae, have phialidic conidiogenesis. Other characterization of condiomata (such as pycnidial, pycnidial wall pseudoparenchymatous, 2-7-layered, outer wall pigmented), conidiogenous cells (phialidic and thin-walled), conidia (aseptate or septate, smooth-walled, and hyaline to brown in a later stage) also fit the description of Neodidymellipsis Chen et al. (2015).

Neodidymelliopsis was recently proposed by Chen et al. (2015) and is characterized by producing globose to flask-shaped, glabrous or pycnidia with hyphal outgrowths. The most characteristic features include its elongated neck, the conidia that are initially hyaline and aseptate but became pale-brown and septate with age [31]. Morphological features of these new fungal isolates collected from citrus in the south of Iran were confirmed that they share Neodidymelliopsis properties by having possessed pycnidial condiomata and phialidic conidiogenesis, with hyaline, ampulliform and thin-walled conidiogenous cells, and none or 1-septate, smooth-walled, hyaline to pale brown conidia. Characterization of conidiomata, conidia and conidiogenous cells of the 
isolates were in consistent with the description of Neodidymelliopsis reported by Chen et al. (2015).

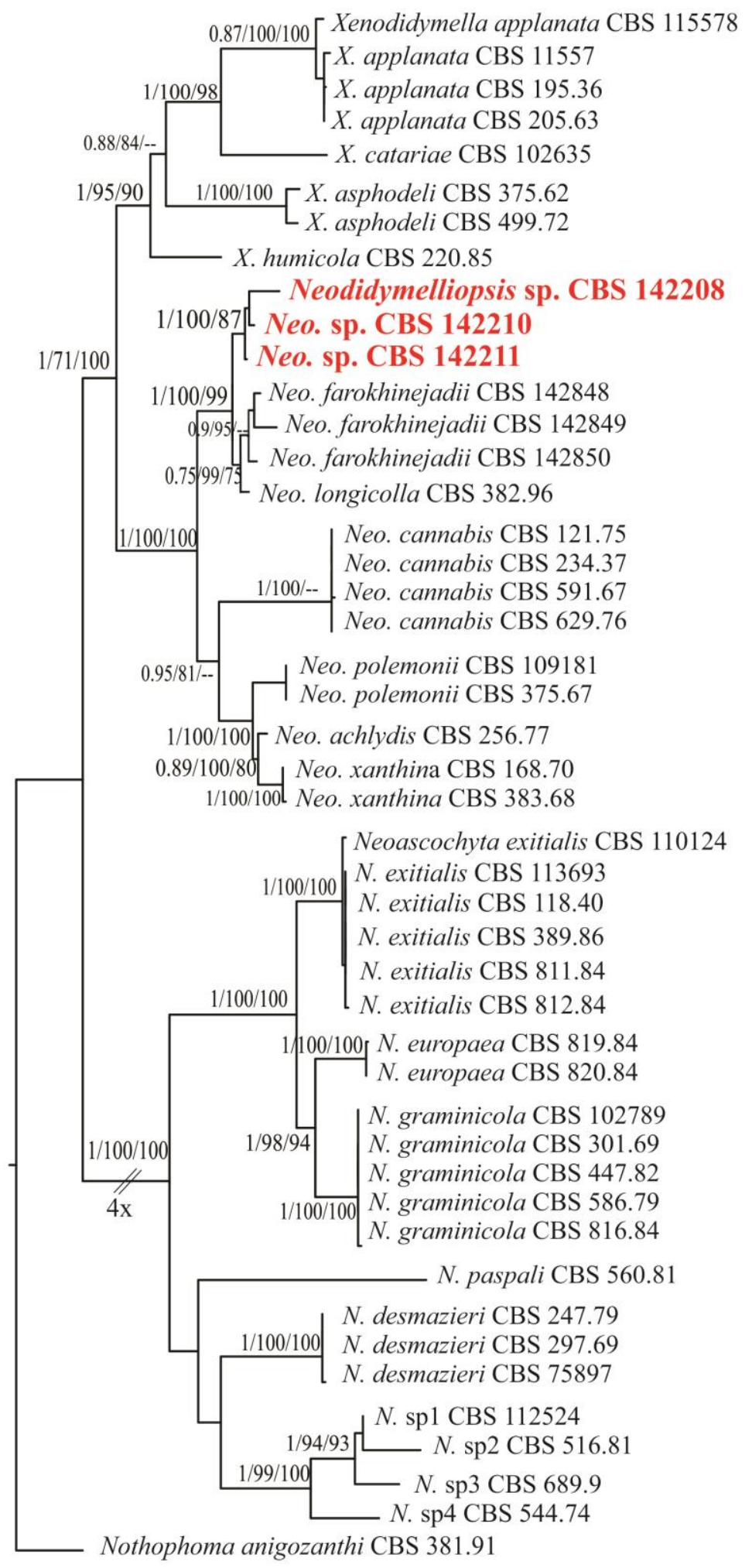

0.03

Fig. 5: Phylogenetic trees generated by Bayesian inference (BI), Maximum likelihood (ML) and maximum parsimony (MP) analysis of the combined dataset of ITS region and $L S U, R P B 2$ and TUB genes

The Bayesian posterior probabilities (BPP), RAxML bootstrap support values (MLBS) and maximum parsimony bootstrap support (MPB) are given at the nodes (BPP/MLBS/MPB). New isolates are in red and the tree is rooted with Nothophoma anigozanthi CBS 381.91. 
In the present study isolates differed morphologically from the six previously described species of Neodidymelliopsis, viz. N. achlydis, N. cannabis, N. farrokhinejadii, N. longoicolla, $N$. polemonii and $N$. xanthine $[4,11,12,31]$. We therefore propose that our isolates comprise a new species, Neodidymelliopsis iranensis Soleimani \& Goudarzi, sp. nov.

$N$. iranensis differs from $N$. polemonii and $N$. xanthina in producing pycnidia with 1-4 ostioles vs. a single ostiole and 0-1 septate conidia vs. aseptate conidia [12] as well as reddishbrown discoloration in $N$. iranensis vs. negative $\mathrm{NaOH}$ reaction in $N$. polemonii [12]; from $N$. achlydis in its septate conidia (0-1-septate vs. aseptate) as well as in $\mathrm{NaOH}$ discoloration (reddishbrown vs. dull green with a reddish brown margin [11]; from $N$. cannabis in the number of pycnidial ostioles (1-4 vs. 1) [9]; from $N$. longicolla in producing smaller pycnidia $(55-283 \times 28$ $221 \mu \mathrm{m}$ vs. $200-490 \times 150-360 \mu \mathrm{m})$ [11] and smaller conidia (4.9-9.29 $\times 2.3-3.48 \mu \mathrm{m}$ vs.12-16.5 $\times 4-7 \mu \mathrm{m})$ [11]; from $N$. farrokhinejadii in pycnidia size $(55-283 \times 28-221 \mu \mathrm{m}$ vs. $120-400 \times 50$ $290 \mu \mathrm{m})[4]$, and conidia size $(4.9-9.29 \times 2.3-3.48 \mu \mathrm{m}$ vs. $5-8(10) \times 2.5-3(5) \mu \mathrm{m}$ (1-cellular conidia), 7-10.25(12.5) $\times 2.5-5 \mu \mathrm{m}$ (2-cellular conidia) [4].

Phylogenetic analyses trees, planted with maximum parsimony, Bayesian and maximum likelihood methods using combination sequence of the ITS region and $L S U, R P B 2$ and TUB genes, showed that our isolates were clustered with Neodidymelliopsis with strong support (1.00 PP / 100\% ML / 100\% MP) and separated from Neodidymelliopsis longicolla CBS 382.96 and N. farrokhinejadii CBS 142850 with a high support (1.00 PP / 100\% ML/99\% MP) as our isolates formed a distinct subclade (1.00 PP / 100\% ML / 87\% MP).

According to our results, the differences observed in this study, including the size of pycnidia and conidia, the number of conidia septa, as well as differential reaction to $\mathrm{NaOH}$ test, have indicated that our isolates are different from those of the other species of Neodidymelliopsis. This separation was confirmed by phylogenetical studies. Finally, based on phylogenetic analyses and morphological properties, we have proposed that our isolates comprise a species of the genus Neodidymelliopsis that is new to science. Hence, we have described our isolates as Neodidymelliopsis iranensis.

\section{Conclusion}

In this study, we have introduced one new species and provided reference (type) specimens for this species. The effects of pathogenicity, host specificity, and biology of the characterized species on disease severity remain obscure and require further studies in the future. In order to develop effective integrated control strategies, the epidemiology of this pathogen needs to be studied further, as well to understand the ecology and the distribution patterns of the pathogen. The most effective means to control disease in plants on a large scale would be to use tolerant or resistant cultivars. Therefore, the citrus species resistant to Neodidymelliopsis should be studied for appropriate management of disease and prevent yield losses.

Conflict of interest disclosure: The authors have no conflict of interest.

\section{REFERENCES}

1. Cacciola, S.O., di San Lio, G.M., 2008, Management of citrus diseases caused by phytophthora spp. A., 
Ciancio, K.G. Mukerji (eds.), Integrated Management of Diseases Caused by Fungi, Phytoplasma and Bacteria, pp 61-84.

2. Mayorquin, J.S., Wang, D.H., Twizeyimana, M., Eskalen A., 2016, Identification, distribution, and pathogenicity of Diatrypaceae and Botryosphaeriaceae associated with citrus branch canker in the southern California desert, Plant Disease, 100: 2402-13.

3. Phillips, A.J.L., Alves, A., Pennycook, S.R., Johnston, P.R., Ramaley, A., Akulov, A., Crous P.W., 2008, Resolving the phylogenetic and taxonomic status of dark-spored teleomorph genera in the Botryosphaeriaceae, Persoonia, 21: 29-55.

4. Chen, Q., Jiang, J.R., Zhang, G.Z., Cai, L., Crous, P.W., 2015, Resolving of Phoma enigma, Studies Mycology, 82: $137-217$.

5. Ahmadpour, S.A., Farokhinejad, R., Mehrabi-Koushki, M., 2017, Further characterization and pathogenicity of Didymella microchlamydospora causing stem necrosis of Morus nigra in Iran, Mycosphere, 8: 835-52.

6. Abdollahzadeh, J., Javadi, A., Mohammadi Goltapeh, E., Zare, R., Phillips, A.J.L., 2010, Phylogeny and morphology of four new species of Lasiodiplodia from Iran, Persoonia, 25: 1-10.

7. Linaldeddu, B.T., Deidda, A., Scanu, B., Franceschini, A., Serra, S., Berraf-Tebbal, A., Zouaoui Boutiti, M., Ben Jamâa, M. L., Phillips, A.J.L., 2014, Diversity of Botryosphaeriaceae species associated with grapevine and other woody hosts in Italy, Algeria and Tunisia, with descriptions of Lasiodiplodia exigua and Lasiodiplodia mediterranea sp. nov., Fungal Divers., 71: 201-14. DOI 10.1007/s13225-014-0301-x

8. Crous, P.W., Phillips, A.J.L., Baxter, A.P., 2000, Phytopathogenic fungi from South Africa, Stellenbosch, South Africa: Department of Plant Pathology Press, University of Stellenbosch Printers.

9. Abdollahzadeh, J., Javadi, A., Zare, R., Phillips, A.J.L., 2014, A phylogenetic study of Dothiorella and Spencermartinsia species associated with woody plants in Iran, New Zealand, Portugal and Spain., Persoonia, 32: $1-12$.

10. Chen, Q., Hou, L.W., Duan, W.J., Crous, P.W., Cai, L., 2017, Didymellaceae revised, Stud. Mycol., 87: 10556.

11. Valenzuela-Lopez, N., Sutton, D.A., Cano-Lira, J.F., Paredes, K., Wiederhold, N., Guarro, J., Stchigel, A.M., 2018, Coelomycetous Dothideomycetes with emphasis on the families Cucurbitariaceae and Didymellaceae, Stud. Mycol., 90: 1-69.

12. Ahmadpour, S.A, Mehrabi-Koushki, M., Farokhinejad, R. 2017, Neodidymelliopsis farokhinejadii, a new fungal species from dead branches of trees in Iran, Sydowia, 69: 171-82. DOI 10.12905/0380.sydowia69-20170171.

13. De Gruyter, J., Aveskamp, M.M., Woudenberg, J.H.C., Verkley, G.J.M., Groenewald, J.Z., Crous, P.W., 2009, Molecular phylogeny of Phoma and allied anamorph genera: Towards a reclassification of the Phoma complex, Mycol. Res.,113: 508-19.

14. Aveskamp, M.M., de Gruyter, J., Crous, P.W., 2008, Biology and recent developments in the systematics of Phoma, a complex genus of major quarantine significance, Fungal Divers., 31: 1-18.

15. Adesemoye, A.O., Mayorquin, J.S., Wang, D.H., Twizeyimana, M., Lynch, S.C., Eskalen, A., 2014, Identification of species of Botryosphaeriaceae causing bot gummosis in citrus in California, Plant Dis., 98: 55-61. http://dx.doi.org/10.1094/PDIS-05-13-0492-RE.

16. Taylor, J.E., Hyde, K.D., 2003, Microfungi of tropical and temperate palms, Fungal Divers. Research Series, 12: $1-459$.

17. Boerema, G.H., Noordeloos, M.E., Hamers, M.E.C., 2004, Phoma identification manual. Differentiation of specific and infra-specific taxa in culture, Wallingford, UK: CABI Publishing.

18. Rayner, R.W., 1970, A mycological colour chart, Kew, UK: Commonwealth Mycological Institute and British Mycological Society.

19. Aveskamp, M.M., Verkley, G.J.M., de Gruyter, J., Woudenberg, J.H.C., Verkley, G.J.M., P.W., 2009, DNA phylogeny reveals polyphyly of Phoma section Peyronellaea and multiple taxonomic novelties, Mycologia, 101: 363-82.

20. Damm, U., Crous, P.W., Fourie, P.H., 2007, Botryosphaeriaceae as potential pathogens of Prunus species in South Africa, with descriptions of Diplodia africana and Lasiodiplodia plurivora sp. nov., Mycologia, 99: 66480.

21. Doyle, J.J., Doyle, J.L., 1987, A rapid DNA isolation procedure for small quantities of fresh leaf tissue, Phytochem. Bull., 19: 11-5. 
22. Rehner, S.A., Samuels, G,J., 1994, Taxonomy and phylogeny of Gliocladium analysed from nuclear large subunit ribosomal DNA sequences, Mycol, Res., 98: 625-34.

23. Vilgalys, R., Hester, M., 1990, Rapid genetic identification and mapping of enzymatically amplified ribosomal DNA from several Cryptococcus species, J. Bacteriol., 172: 4238-46.

24. De Hoog, G.S., Gerrits, van den E.A.H.G., 1998, Molecular diagnostics of clinical strains of filamentous Basidiomycetes, Mycoses., 41: 183-9.

25. White, T.J., Bruns, T., Lee, S., Taylor, J., 1990, Amplification and direct sequencing of fungal ribosomal RNA genes for phylogenetics. In: PCR protocols: a guide to methods and applications, Innis MA, Gelfand DH, Sninsky JJ, White TJ, (eds.), Academic Press, San Diego, California, USA.

26. Sung, G.H., Sung, J.M., Hywel-Jones, N.L., Spatafor, J.W., 2007, A multi-gene phylogeny of Clavicipitaceae (Ascomycota, Fungi): identification of localized incongruence using a combinational bootstrap approach, Mol. Phylogenet. Evol., 44: 1204-23.

27. Liu, Y.J., Whelen, S., Hall, B.D., 1999, Phylogenetic relationships among ascomycetes: evidence from an RNA polymerase II subunit, Mol. Biol. Evol., 16: 1799-808.

28. Woudenberg, J.H.C., Aveskamp, M.M., de Gruyter, J., Spiers, A.G., Crous, P.W., 2009, Multiple Didymella teleomorphs are linked to the Phoma clematidina, Persoonia, 22: 56-62.

29. Aveskamp, M.M., de Gruyter, J., Woudenberg, J.H.C., Woudenberg, J.H.C., Verkley, G.J.M., Crous, P.W., 2010, Highlights of the Didymellaceae: a polyphasic approach to characterise Phoma and related, Stud. Mycol., 65: $1-60$.

30. Nylander, J.A.A., 2004, MrModeltest 2.2. Program distributed by the author. Uppsala, Sweden: Evolutionary Biology Centre, Uppsala University.

31. Swofford, D.L., 2003, PAUP*: phylogenetic analysis using parsimony (*and other methods). Version 4.0b 10. Sunderland, Massachusetts: Sinauer Associates.

32. Huelsenbeck, J.P., Ronquist, F., 2001, MrBayes: Bayesian inference of phylogenetic trees, Bioinformatics, 17: 754-5.

33. Stamatakis, A., Hoover, P., Rougemont, J., 2008, A rapid bootstrap algorithm for the RAxML Web-Servers, Syst. Biol., 75: 758-71.

34. Page, R.D.M., 1996, Treeview: an application to display phylogenetic trees on personal computers, Bioinformatics, 12: 357-8.

\section{FILOGENIA ȘI MORFOLOGIA SPECIEI NEODIDYMELLIOPSIS IRANENSIS SP. NOV. CE CAUZEAZĂ NECROZA RAMURILOR DE CITRUS ÎN IRAN}

\section{(Rezumat)}

Citricele, care sunt cel mai mult cultivate în partea sudică, tropicală a țării, reprezintă una dintre cele mai importante culturi din Iran. Cancerul ramurilor și necroza citricelor este o problemă permanentă pentru cultivatorii de citrice din aceste zone și a produs pagube totale pentru producția de citrice din ultimii ani. Simptomele bolii constau în afectarea lăstarilor cu creștere viguroasă, cancerul ramurilor și a trunchiului portaloiului. În acest studiu ne-am propus caracterizarea patogenului din punct de vedere morfologic şi filogenetic. Specia nouă Neodidymelliopsis iranensis, sp. nov. este descrisă și ilustrată în acest studiu. Izolatele au provenit de la mostre de ramuri cu simptome specifice. După obținerea culturilor pure din spori unici pe medii de cultură cu ovăz și malț-agar, au fost descrise caracterele morfologice ale speciei și s-a testat patogenicitatea acestora pe lămâi (Citrus aurantifolia). Din punct de vedere morfologic, $N$. iranensis se separă ușor de alte specii de Neodidymelliopsis in funcție de mărimea picnidiilor, septele conidiilor și rezultatul testelor $\mathrm{NaOH}$. Diferențele de morfologie dintre izolatele obținute și alte specii cunoscute de Neodidymelliopsis au fost confirmate și de analiza filogenetică multi-locus pe baza regiunii ITS şi a genelor LSU, RPB2 şi TUB2. În arborele filogenetic reconstruit, N. iranensis formează un grup distinct cu alte specii de Neodiddymelliopsis din familia Didymellaceae, însă este separat de alte specii de Neodiddymelliopsis. Poziția filogenetică distinctă este confirmată și de diferențele morfologice. În consecință, specificitatea caracterelor morfologice și filogenetice ale izolatelor obținute ne-au determinat să le descriem ca fiind Neodidymelliopsis iranensis, sp. nov. 